\title{
MICROMORPHOLOGICAL AND ANATOMICAL CHARACTERS OF THE TURKISH ENDEMIC Marrubium trachyticum Boiss. (LAMIACEAE)
}

\author{
Tülay AYTAŞ AKÇİN*, Burcu CAMILİ \\ Ondokuz Mayıs University, Faculty of Arts and Science, Department of Biology, 55139 Samsun, TURKEY \\ *Corresponding author: e-mail: aytasakcin@hotmail.com \\ Cite this article as: \\ Aytaş Akçin T. \& Camili B. 2018. Micromorphological and Anatomical Characters of the Turkish Endemic Marrubium trachyticum Boiss. \\ (Lamiaceae). Trakya Univ J Nat Sci, 19(1): 77-83, DOI: 10.23902/trkjnat.373647
}

Received: 02 January 2018, Accepted: 05 April 2018, Online First: 07 April 2018, Published: 15 April 2018

\begin{abstract}
In the present study, micromorphological characters of stem, leaf, calyx and mericarp of the Turkish endemic Marrubium trachyticum Boiss were investigated using scanning electron microscopy (SEM) and the anatomy of root, stem and leaf using light microscopy (LM). Stellate trichomes with unequal rays and branched hairs were observed on the stem, leaf and calyx. The distributions and densities of glandular trichomes on these vegetative organs were less than the eglandular trichomes. The mature mericarps of the species were ovate in shape and sculpturing pattern was penta-hexagonal colliculate. According to the anatomical results, $M$. trachyticum has secondary root structure. The stem has a distinct collenchyma layer. The stem is surrounded by oval or rectangular epidermal cells with a thick cuticle and is quadrangular in shape. The leaves are bifacial (dorsiventral) with anomocytic stomata in both the upper and the lower surfaces.
\end{abstract}

Key words: Anatomy, Lamiaceae, Scanning electron microscopy (SEM), Turkey.

\begin{abstract}
Özet: Bu çalışmada, Türkiye için endemik bir tür olan Marrubium trachyticum Boiss.'un taramalı elektron mikroskobu (SEM) kullanılarak gövde, yaprak, kaliks ve fındıkçığının mikromorfolojik özellikleri ve 1şı mikroskobu kullanılarak kök, gövde ve yaprak anatomisi araştırıldı. M. trachyticum'un gövde, yaprak ve kaliksi üzerinde eşit olmayan 1şınlı stellat tüyler ve dallanmış tüyler gözlendi. Bununla beraber, M. trachyticum'un bu vejetatif organları üzerindeki salgı tüylerinin dağılışı ve yoğunluğu, örtü tüylerinden daha azdır. Türün olgun findıkçıkları, ovat şekilliydi ve yüzey süslemesi penta-hexagonal colliculate (beşgenaltıgen şekilli kabartıl1)'dir. Anatomik sonuçlara göre, araştırılan tür, sekonder kök yapısına sahiptir. Gövdenin belirgin bir kollenkima tabakasına sahip olduğu gözlendi. Gövde enine kesiti dört köşelidir ve ince bir kutikulaya sahip oval veya dikdörtgen epidermis hücreleri ile çevrilidir. M. trachyticum'un yaprakları bifasiyaldir (dorsiventral). Bu tür, yaprağın hem alt hem de üst yüzeyinde anomositik tip stomalara sahiptir.
\end{abstract}

\section{Introduction}

The genus Marrubium L. belongs to the Lamiaceae family and includes annual and perennial herbs. The species of the genus have an important distribution in Irano-Turanian and Mediterranean phytogeographic regions. The genus comprises about 40 taxa throughout the world (Hedge 1992) and is represented in Turkey by 21 taxa of which 12 are endemic (Cullen 1982, Davis et al. 1988, Ekim et al. 2000, Aytaç et al. 2012). It is thought that Turkey is the main centre of diversity for the genus Marrubium (Akgül \& Ketenoğlu 2014). M. trachyticum Boiss., growing in steppe, slopes and fields inside the altitude range from 900 to $2500 \mathrm{~m}$ a.s.l. (Cullen 1982), is one of the endemic species of the genus in Turkey and has been included in the Red Data Book of Turkish Plants in near threatened (LR-nt) status (Ekim et al. 2000).

Marrubium has been used as a traditional medicine for asthma, pulmonary infections, inflammation, and hypotension and also as pain reliever (Meyre-Silva \&
Cechinel-Filho 2010). Furthermore, there are some reports on Marrubium species about their effects on reducing oxidative stress and inflammatory reactions due to their high amount of polyphenol and flavonoid contents (Yousefi et al. 2013, 2014). However, studies on Marrubium focused mainly on palynological, micromorphological and chemical features of the taxa studied (Akgül et al. 2008, Ahvazi et al. 2016, Kharazian \& Hashemi 2017). Pollen and seed micromorphology generally support identifications of members of some genera such as Marrubium and Stachys L. (Abu-Assab \& Cantino 1994).

Trichomes are the most useful taxonomic characters in the Lamiaceae family and taxonomical significance of trichome structure in this family is well known (AbuAssab \& Cantino 1987, Marin et al. 1994, Navarro \& El Qualidi 2000, Kahraman et al. 2011, Celep et al. 2014, Atalay et al. 2016, Haratym \& Werszko-Chmielewska 
2017). Trichomes are widely distributed in the vegetative and reproductive parts of plants of Lamiaceae and distinguished as glandular and non-glandular trichomes (Cantino 1990, Navarro \& El- Qualidi 2000). Glandular hairs are widely distributed over the aerial reproductive and vegetative organs of members of the family and their structures have been investigated in a number of studies (Bosabilidis 1990, Ascensao et al. 1999, Kaya et al. 2003). However, non-glandular trichomes are more common than glandular trichomes within Lamiaceae (Cantino 1990).

Studies on mericarp micromorphology in Lamiaceae have been a useful tool for classification within the family (Navarro \& El Qualidi 2000, Dinç \& Doğan 2006, Kaya $\&$ Dirmenci 2008). The usefulness of nutlet micromorphological characters in Lamiaceae taxonomy were also proved (Jamzad et al. 2000, Guerin 2005, Moon \& Hong 2006, Kahraman et al. 2011). Furthermore, the importance of analysis based on Scanning Electron Microscopy (SEM) has been reported in many genera of the family (Budantsev \& Lobova 1997, Jamzad et al. 2000, Kahraman et al. 2011, Sat1l et al. 2012).

There exist many anatomical studies concerning Lamiaceae in Turkey (Kaya et al. 2000, Uysal 2003, Erken 2005, Celep et al. 2011). Although some of these studies are related with Marrubium species, detailed investigations and publications on anatomical and micromorphological characters of Turkish endemic $M$. trachyticum are very limited (Akgül 2004, Büyükkartal et al. 2016). The present study is the first comprehensive study of anatomy and micromorphology of this endemic species.

The aim of this study is to investigate the detailed characteristics of micromorphological structures of stem, leaf, calyx and mericarp of M. trachyticum using SEM and its anatomy of root, stem and leaf using light microscopy.

\section{Materials and Methods}

Plant samples were collected from May to July 2014 from natural populations in the vicinity of Bağc1lı village in Çorum, Turkey. The specimens were dried according to standard herbarium techniques and stored in the Ondokuz Mayıs University, Faculty of Art and Science Herbarium (OMUB). The taxonomical descriptions of the plants were made according to Flora of Turkey (Cullen 1982).

Dried stem, leaf, calyx and mericarp samples were mounted directly on stubs using double-sided adhesive tape for SEM investigations. The stubs were coated with gold for 5 minutes and then observed and photographed in JEOL-JSM 7001 Scanning Electron Microscope. The terminology of Cantino (1990) and Koul et al. (2000) was followed for micromorphological investigations.

Anatomical investigations were performed using an average of 30 fresh specimens which were kept in $70 \%$ alcohol. Transverse sections of roots, stems and leaves and surface sections of leaves were used to make permenant/temporary slides and the slides were viewed and photographed using a Nikon Coolpix 5200 digital camera. All anatomical measurements were done in computer media based on the photographs with the help of the Image J program. Stomatal index was calculated according to the method described by Meidner \& Mansfield (1968) for both surfaces of the epidermis.

\section{Results}

\section{Micromorphological characteristics}

Observation of stem using SEM showed that eglandular and glandular trichomes are present on stems of M. trachyticum (Fig. 1A-B). Lanate eglandular trichomes, in particular, are more abundant at the base of the stem. The head of glandular trichomes with short stalk are composed of a spheric cell (Fig. 1B).

Leaf surface is more or less densely covered with eglandular stellate trichomes and eglandular trichomes on the abaxial surface are longer than the adaxial surface (Fig. 1C-D). Glandular trichomes are rare on both side of leaf surfaces. The leaves of the investigated species are amphistomatous and with anomocytic stomata (Fig. 1C). The mean number of stomata per $\mathrm{mm}^{2}$ of leaf surface is $15.01 \pm 3.01$ on adaxial epidermis and $25.64 \pm 4.89$ on the abaxial epidermis (Table 1). Stomata are more abundant on the abaxial side of the leaf. The upper and lower epidermis consist of cells with strongly sinous walls (Fig. 1C-D).

SEM observation showed that the throat of calyx has more greyish stellate trichomes (Fig. 1E). However, these trichomes are more sparsely on the calyx teeth (Fig. 1F). The distribution and density of the glandular trichomes on calyx are less than eglandular ones (Fig. 1E-F).

The mature mericarps are ovate in outline $(1.01 \times 2.05 \mathrm{~mm})$ and dark-brown in color (Fig. 1G). The sculpturing pattern of mature mericarps are pentahexagonal colliculate (Fig. 1H).

\section{Anatomical characteristics}

Root anatomy

The root structure in $M$. trachyticum is more or less uniform. In cross-sections, the periderm layer on the outermost surface is multilayered (Fig. 2A). Cortex consists of 11-12 layers of oval or rectangular parenchymatous cells. Cambium and phloem cells are distinguishable. The thickness of phloem layer is $59.99 \pm 8.27 \mu \mathrm{m}$ (Table 2). The xylem consists of vessel members and tracheids. The xylem rays are composed of 7-8 rowed rectangular cells. The pith is completely filled with xylem elements.

Table 1. Stomata index of leaf of M. trachyticum.

\begin{tabular}{cc}
\hline \hline Stomata index & Mean \pm SD \\
\hline \hline Upper leaf surface & $15.01 \pm 3.01$ \\
Lower leaf surface & $25.64 \pm 4.89$ \\
\hline \hline
\end{tabular}

SD: Standard deviation 

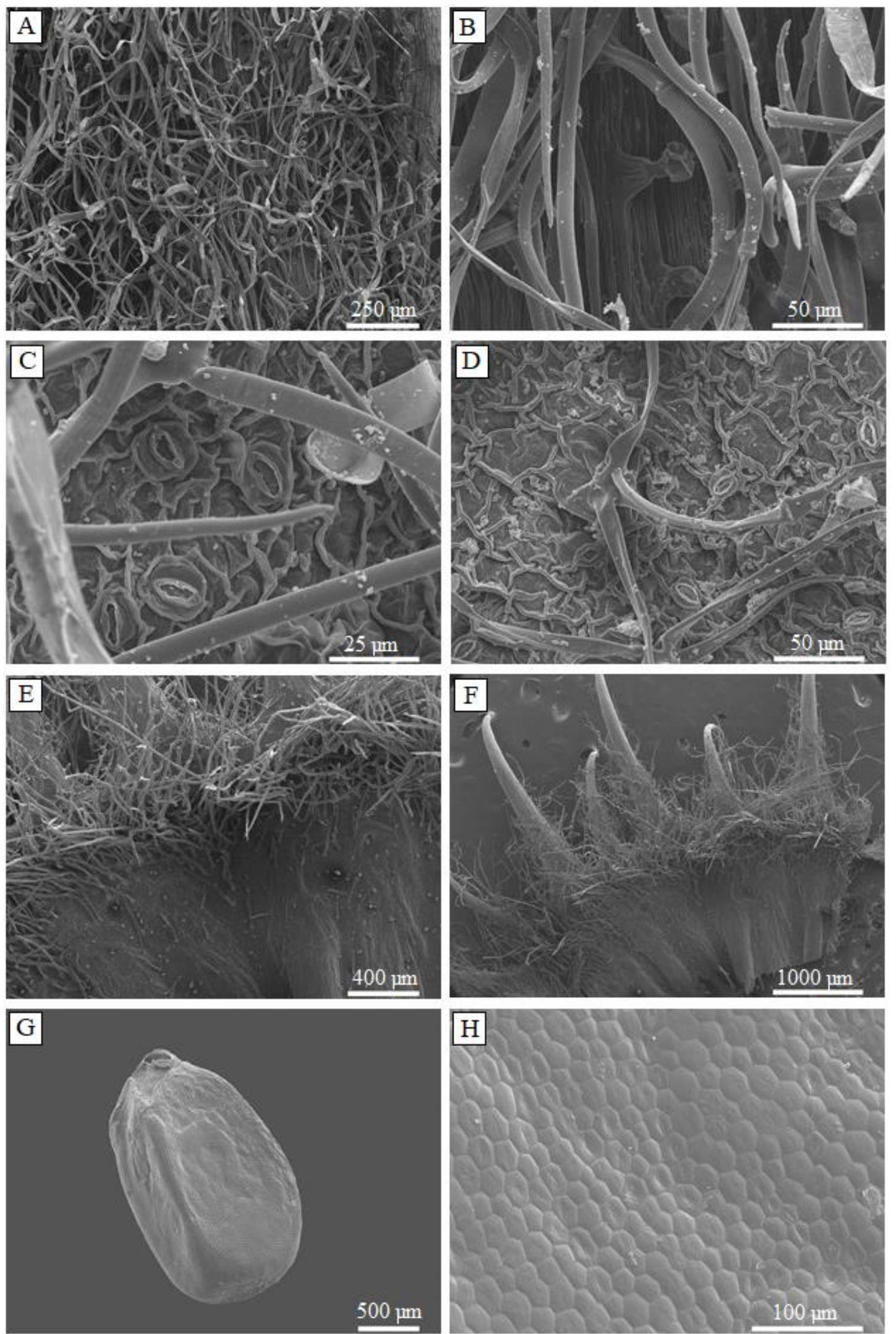

Fig. 1. Scanning electron micrographs (SEM) of M. trachyticum. A-Eglandular trichomes on stem. B-Glandular trichomes on stem. CUpper surface of leaf. D-Lower surface of leaf. E-Trichomes on the calyx throat. F-Trichomes on the calyx teeth. G-General appearance of mericarps. H-Surface details of mericarps. 


\section{Stem anatomy}

Cross-section of the stem is clearly quadrangular in shape. The epidermis consists of oval or rectangular cells and is covered by a thick cuticle. There are one-celled or multicellular non-glandular or glandular hairs on the epidermis (Fig. 2B). The collenchyma tissue consisting of 10-12 layers of ovoidal cells is located underneath the epidermis. The cortex tissue is composed of ovoidal and quadrangular cells with thin walls and the thickness of this layer is $130.70 \pm 23.31 \mu \mathrm{m}$ (Fig. 2B, Table 2). Beneath the cortex parenchyma, small groups of phloem sclerenchyma cells are located above the phloem and vascular cambium is indistinguishable. Xylem elements are thick-walled. The mean diameter of vessel elements is $20.20 \pm 4.35 \mu \mathrm{m}$ (Table 2). The pith consists of large and cylindrical parenchymatic cells and pith cells become smaller towards the central part of the stem (Fig. 2B).
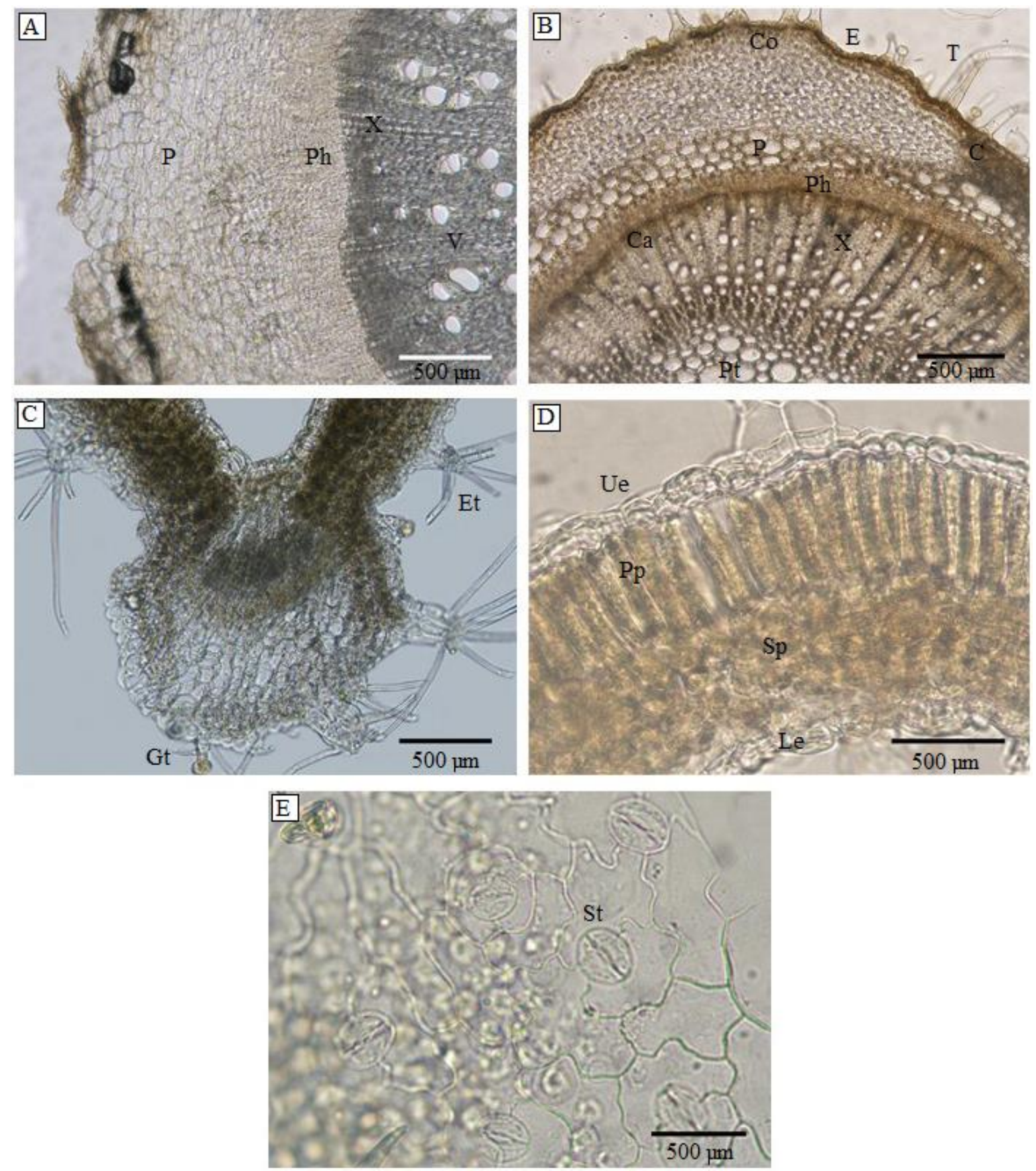

Fig. 2. Root, stem and leaf anatomical structures of M. trachyticum. A-Cross-sections of the root (A), the stem (B) and the leaf (C, D). E- Lower surface of the leaf. (C-cortex, Ca-cambium, Co-collenchyma, E-epidermis, Et-eglandular trichome, Gt-glandular trichome, Le-lower epidermis, P-parenchyma, Ph-phloem, Pp-palisade parenchyma, Pt-pith, Sp-spongy parenchyma, St-stomata, T-trichome, Ue-upper epidermis, V-vessel elements). 
Table 2. Anatomical characteristics of $M$. trachyticum.

\begin{tabular}{|c|c|c|c|}
\hline & & $\begin{array}{l}\text { Width }(\mu \mathrm{m}) \\
(\text { mean } \pm \text { SD })\end{array}$ & $\begin{array}{c}\text { Length }(\mu \mathrm{m}) \\
(\text { mean } \pm \mathrm{SD}) \\
\end{array}$ \\
\hline \multirow{5}{*}{ Root } & Thickness of periderm & $36.46 \pm 6.56$ & - \\
\hline & Parenchyma cells & $23.65 \pm 5.97$ & $15.77 \pm 3.94$ \\
\hline & Thickness of phloem & $59.99 \pm 8.27$ & - \\
\hline & Thickness of xylem & $443.34 \pm 27.42$ & - \\
\hline & Diameter of vessels & $24.68 \pm 7.76$ & - \\
\hline \multirow{8}{*}{ Stem } & Thickness of epidermis & $71.79 \pm 2.91$ & - \\
\hline & Parenchyma cells & $20.22 \pm 3.99$ & $12.60 \pm 2.87$ \\
\hline & Thickness of cortex & $130.70 \pm 23.31$ & - \\
\hline & Thickness of collenchyma & $163.17 \pm 33.31$ & - \\
\hline & Thickness of phloem & $49.11 \pm 12.77$ & - \\
\hline & Thickness of xylem & $114.42 \pm 40.50$ & - \\
\hline & Diameter of vessels & $20.20 \pm 4.35$ & - \\
\hline & Pith cells & $26.66 \pm 8.75$ & $20.65 \pm 7.80$ \\
\hline \multirow{6}{*}{ Leaf } & Upper epidermis cells & $9.81 \pm 2.28$ & $6.93 \pm 0.97$ \\
\hline & Thickness of palisade parenchyma & $41.29 \pm 2.47$ & - \\
\hline & Thickness of spongy parenchyma & $39.71 \pm 2.56$ & - \\
\hline & Lower epidermis cells & $10.38 \pm 3.00$ & $10.52 \pm 2.89$ \\
\hline & Adaxial stomata & $22.22 \pm 1.22$ & $26.72 \pm 0.62$ \\
\hline & Abaxial stomata & $18.73 \pm 1.39$ & $19.46 \pm 2.11$ \\
\hline
\end{tabular}

SD: Standard deviation

Leaf anatomy

In transverse sections, the upper and the lower epidermises comprise of uniseriate, quadrangular and oval cells. However, lower epidermal cells are larger than upper epidermis cells (Table 2). Both epidermises are covered with non-glandular and glandular hairs (Fig. 2C). 2-3 layers of collenchyma cells are present in the midrib located between the upper and the lower epidermis. The leaves are bifacial (dorsiventral) (Fig. 2D). Palisade tissue is composed of 1-2 layered cylindrical cells with e plenty of chloroplasts. Spongy parenchyma with large intercellular spaces are round or irregular in shape and the thickness of this layer is $39.71 \pm 2.56 \mu \mathrm{m}$ (Fig. 2D, Table 2). Vascular bundles are collateral type. In their surface views, the leaves are amphistomatic and epidermal cells have wavy walls (Fig. 2E). Adaxial stomata length and width is higher than the abaxial stomata dimensions (Table 2). The number of stomata per $\mathrm{mm}^{2}$ in lower surface is higher than in upper surface (Table 1).

\section{Discussion}

In this study, micromorphological and anatomical properties of $M$. trachyticum studied by light and scanning electron microscopies were determined to be useful characters.

The taxonomic significance of trichome micromorphology in some members of Lamiaceae has already been evident (Dinç et al. 2009, Xiang et al. 2010, Kahraman et al. 2010, Osman 2012, Celep et al. 2014). This study shows that the main hair type in M. trachyticum is stellate with unequal rays and branched hairs. Stellate and branched hairs have been previously reported in some other genera of Lamiaceae such as Stachys L. (Salmaki et al. 2009), Nepeta L. (Jamzad 2001), Lavandula L. (Upson \& Andrews 2004) and Phlomis L. (Azizian \& Cutler 2008). Our findings are consistent with the results of
Seyedi \& Salmaki (2015) and Ahvazi et al. (2016) indicating that the stellate and branched hairs were found to be in Lamiaceae family members. However, in the present study, the distributions and densities of glandular trichomes on stem, leaf and calyx of M. trachyticum are less than the non-glandular trichomes. It was previously reported that non-glandular trichomes are more common than glandular trichomes in Lamiaceae (Cantino 1990, Osman 2012, Ahvazi et al. 2016).

Mericarp surface sculpturing patterns have diagnostic value for species recognition in some members of Lamiaceae (Jamzad et al. 2003, Kaya \& Dirmenci 2008, Kahraman et al. 2010). Furthermore, the importance of the micromorphology of mericarp surfaces has been determined for Marrubium (Akgül 2004). Akgül et al. (2008) reported that the ornamentation surface in Marrubium species is verrucate and the seed shape in the Turkish Marrubium species can be related to their habitat. Similar results were also reported by Aytaç et al. (2012). According to the findings of our investigations, the mericarp surface in $M$. trachyticum is penta-hexagonal colliculate. Our results confirmed previous studies investigating the mericarp surface in Marrubium genus (Akgül et al. 2008, Aytaç et al. 2012).

Marrubium trachyticum was found to have the same general root anatomy characteristics as in other members of the Lamiaceae family. In root cross sections, the protective tissue was comprised of periderm and the center of the root was composed of tracheary elements. It was previously determined that the pith rays of some species within Lamiaceae, e.g. Lamium lycium Boiss. are 1-4 rowed while Salvia chrysophylla Stapf. has 1-24 rowed and $S$. quezelii Hedge \& Afzal-Rafii has 1-3 (-4) rowed pith rays (Baran \& Özdemir 2009, Kahraman et al. 2010, Celep et al. 2014). Root transverse sections showed that $M$. trachyticum has 7-8 rows of ray cells. 
Watson \& Dalwitz (1978) stated that stems of many members of the Lamiaceae family are quadrangular with well-defined collenchyma on each corners. This character was previously reported in some other Marrubium species (Akgül et al. 2008, Büyükkartal et al. 2016, Tüylü et al. 2017). A well developed multilayered collenchyma was distinguishable at the corners of the stem of $M$. trachyticum. Vessel elements were more distinct in stem. The pith cells were parenchymatic becoming smaller towards the central part of the stem.

Anatomical studies showed that the leaves of the $M$. trachyticum was bifacial (dorsiventral). Palisade parenchyma cells were presented in upper surface of the leaf and spongy parenchyma cells had large intercellular spaces in the lower surface. These leaf anatomy

\section{References}

1. Abu-Asab, M.S. \& Cantino, P.D. 1994. Systematic implications of pollen morphology in subfamily Lamioideae and Pogostemonoideae (Labiatae). Annals of the Missouri Botanical Garden, 81(4): 653-686.

2. Abu-Asab, M.S. \& Cantino, P.D. 1987. Phylogenetic implications of leaf anatomy in subtribe Melittidinae (Labiatae) and related taxa. Journal of the Arnold Arboretum, 68: 1-34.

3. Ahvazi, M., Jamzad, Z., Balali, G.R. \& Saeidi, H. 2016. Trichome micro-morphology in Marrubium L. (Lamiaceae) in Iran and the role of environmental factors on their variation. Iranian Journal of Botany, 22(1): 39-58.

4. Akgül, G. 2004. The revision of the genus Marrubium L. (Lamiaceae) of Turkey PhD. thesis, Institute of Science and Technology, Ankara University, Ankara-Turkey.

5. Akgül, G. \& Ketenoğlu, O. 2014. A new subpecies for Flora of Turkey, Marrubium cephalanthum Boiss. \& Noe subsp. montanum Akgul \& Ketenoğlu (Lamiaceae). Ot Sistematik Botanik Dergisi, 21(1): 21-28.

6. Akgül, G., Ketenoğlu, O., Pınar, N.M. \& Kurt, L. 2008. Pollen and seed morphology of the genus Marrubium L. (Labiatae) in Turkey. Annales Botanici Fennici, 45: 1-10.

7. Ascensao, L., Mota, L. \& Castro, M.D.M. 1999. Glandular trichomes on the leaves and flowers of Plectranthus ornatus: Morphology, distribution and histochemistry. Annals of Botany, 84(4): 437-447.

8. Atalay, Z., Celep, F., Bilgili, B. \& Doğan, M. 2016. Pollen morphology of the genus Lamium (Lamiaceae) and its systematic implications. Flora, 219: 68-84.

9. Aytaç, Z., Akgül, G. \& Ekici, M. 2012. A new species of Marrubium (Lamiaceae) from Central Anatolia, Turkey. Turkish Journal of Botany, 36: 443-449.

10. Azizian, D. \& Cutler, D.F.F. 2008. Anatomical, cytological and phytochemical studies on Phlomis L. and Eremostachys Bunge (Labiatae). Botanical Journal of the Linnean Society, 85(4): 249-281.

11. Baran, P. \& Özdemir, C. 2009. The morphological and anatomical properties of Lamium lycium (Lamiaceae) endemic to Turkey. Nordic Journal of Botany, 27: 388-396. characteristics coincide with those previously reported by Akgül et al. (2008) and Büyükkartal et al. (2016) for some other Marrubium species. In leaf cross-sections, vascular bundles were collateral type in $M$. trachyticum and the phloem surrounded xylem. Our observation showed that M. trachyticum has amphistomatic leaves. Akgül (2004) and Tüylü et al. (2017) also reported that the leaves of the some other Marrubium species are amphistomatic. In surface sections of leaf, anomocytic type stomata were observed with higher numbers in abaxial surface of the leaf.

In conclusion, some characteristic micromorphological and anatomical features of M. trachyticum were reported in detail. The results presented here have the potential to contribute to further taxonomic studies of the genus.

12. Bosabalidis, A.M. 1990. Glandular trichomes in Satureja thymbra leaves. Annals of Botany, 65: 71-78.

13. Budantsev, A.L. \& Lobova, T.A. 1997. Fruit morphology, anatomy and taxonomy of Tribe Nepeteae (Labiatae). Edinburgh Journal of Botany, 54(2): 183-216.

14. Büyükkartal, H.N., Çölgeçen, H. \& Akgül, G. 2016. Comparative leaf, stem and root anatomies of taxa Marrubium bourgaei and Marrubium heterodon (Lamiaceae). Australian Journal of Crop Science, 10(11): 1516-1522.

15. Cantino, P.D. 1990. The phylogenetic significance of stomata and trichomes in the Labiatae and Verbenaceae. Journal of the Arnold Arboretum, 71(3): 323-370.

16. Celep, F., Kahraman, A., Atalay, Z. \& Doğan, M. 2011. Morphology, anatomy and trichome properties of Lamium truncatum Boiss. (Lamiaceae) and their systematic implications. Australian Journal of Crop Science, 5(2): 147-153.

17. Celep, F., Kahraman, A., Atalay, Z. \& Doğan, M. 2014. Morphology, anatomy, palynology, mericarp and trichome micromorphology of the rediscovered Turkish endemic Salvia quezelii (Lamiaceae) and their taxonomic implications. Plant Systematic and Evolution, 300: 19451958.

18. Cullen, J. 1982. Marrubium L. In: Davis, P.H. (eds), Flora of Turkey and the Aegean Islands. Vol. 7. Edinburgh University Press, Edinburgh, 165-178.

19. Davis, P.H., Mill, R.R. \& Kit, T. 1988. Flora of Turkey and the East Aegean Islands. Suppl. 1. Edinburgh University Press, Edinburgh, 202-203.

20. Dinç, M. \& Doğan, H.H. 2006. Stachys yildirimlii Dinc (Lamiaceae), a new species from South Anatolia, Turkey. Annales Botanici Fennici, 43: 143-147.

21. Dinç, M., Pınar, N.M., Doğu, S. \& Yıldırımlı, Ş. 2009. Micromorphological studies of Lallemantia L. (Lamiaceae) species growing in Turkey. Acta Biologica Cracoviensia Series Botanica, 51(1): 45-54.

22. Ekim, T., Koyuncu, M., Vural, M., Duman, H., Aytaç, Z. \& Adıgüzel, N. 2000. Türkiye Bitkileri Kırmızı Kitabı, Van Y.Y. Üniversitesi Doğa Derneği, Barışcan Ofset, Ankara, 246 pp. 
23. Erken, S. 2005. Morphological and Anatomical Studies on Thymbra sintenisii Bornm. \& Aznav. (Labiatae). Turkish Journal of Botany, 29: 389-397.

24. Guerin, G.R. 2005. Nutlet morphology in Hemigenia R.Br. and Microcorys R.Br. (Lamiaceae). Plant Systematic and Evolution, 254(1/2): 49-68.

25. Haratym, W. \& Weryszko-Chmielewska E. 2017. Ultrastructural and histochemical analysis of glandular trichomes of Marrubium vulgare L. (Lamiaceae). Flora, 231: 11-20.

26. Hedge, I.C. 1992. A global survey the biogeography of the Labiatae, Royal Botanic Gardens, Kew. Science, 7-17.

27. Jamzad, Z. 2001. A phylogenetic study of Nepeta L. (Lamiaceae). Ph. D. thesis, Birkbeck College, University of London.

28. Jamzad, Z., Harley, M.M., Ingrouille, M., Simmonds, M.S.J. \& Jalili, A. 2000. Pollen exine and nutlet surface morphology of the annual species of Nepeta L. (Lamiaceae) in Iran. Pp. 385-397. In: Harley M.M., Morton, G.M. \& Blackmore, S. (eds). Pollen and Spores: Morphology and Biology. Royal Botanic Gardens, Edinburgh, 567 pp.

29. Jamzad, Z., Ingrouille, M. \& Simmonds M.S.J. 2003. Three new species of Nepeta L. (Lamiaceae) from Iran. Taxon, 52(1): 93-98.

30. Kahraman, A., Celep, F. \& Doğan, M. 2010. Anatomy, trichome morphology and palynology of Salvia chrysophylla Stapf (Lamiaceae). South African Journal of Botany, 76: 187-205.

31. Kahraman, A., Celep, F., Doğan, M., Guerin, G.R. \& Bagherpour, S. 2011. Mericarp morphology and its systematic implications for the genus Salvia L. section Hymenosphace Benth. (Lamiaceae) in Turkey. Plant Systematic and Evolution, 292(1/2): 33-39.

32. Kaya, A. \& Dirmenci, T. 2008. Nutlet surface micromorphology and taxonomy of species of the genus Nepeta L. (Lamiaceae) in Turkey. Turkish Journal of Botany, 32: 103-112.

33. Kaya, A., Başer, K.H.C., Satıl, F. \& Tümen, G. 2000 Morphological and anatomical studies on Cyclotrichium origanifolium (Labill.) Manden and Scheng. (Labiatae). Turkish Journal of Botany, 24: 273-278.

34. Kaya, A., Demirci, B. \& Başer, K.H.C. 2003. Glandular trichomes and essential oils of Salvia glutinosa L. South African Journal of Botany, 69: 422-427.

35. Kharazian, N. \& Hashemi, M. 2017. Chemotaxonomy and morphological studies in five Marrubium L. species in Iran. Iran Journal of Science Technology Transactions A: Science, 41: 17-31.

36. Koul, K.K., Ranjna, N. \& Raina, S.N. 2000. Seed coat microsculturing in Brassica and allied genera (subtribes Brassicinae, Raphaninae, Moricandiinae). Annals of Botany, 86: 385-397.

37. Marin, D.P., Petkovic, B. \& Duletic, S. 1994. Nutlet sculpturing of selected Teucrium species (Lamiaceae): a character of taxonomic significance. Plant Systematic and Evolution, 192: 199-214.
38. Meidner, H. \& Mansfield, T.A. 1968. Physiology of Stomata, McGraw-Hill, London, 178 pp.

39. Meyre-Silva, C.H. \& Cechinel-Filho, V. 2010. A review of the chemical and pharmacological aspects of the genus Marrubium. Current Pharmaceutical Design, 16: 35033518.

40. Moon, H.K. \& Hong, S.P. 2006. Nutlet morphology and anatomy of the genus Lycopus (Lamiaceae: Menthae). Journal of Plant Research, 119(6): 63-64.

41. Navarro, T. \& El Qualidi, J. 2000. Trichome morphology in Teucrium L. (Labiatae). A taxonomic review. Annales de Jardin Botanico de Madrid, 57(2): 277-297.

42. Osman, A.K. 2012. Trichome micromorphology of Egyptian Ballota (Lamiaceae) with emphasis on its systematic implication. Pakistan Journal of Botany, 44(1): 33-46.

43. Salmaki, Y., Zarre, S.H., Jamzad, Z. \& Brauchler, C. 2009. Trichome micromorphology of Iranian Stachys (Lamiaceae) with emphasis on its systematic implication. Flora, 204: 371-381.

44. Sat1l, F., Kaya, A., Akcicek, E. \& Dirmenci, T. 2012. Nutlet micromorphology of Turkish Stachys sect. Eriostomum (Lamiaceae) and its systematic implications. Nordic Journal of Botany, 30: 352-364.

45. Seyedi, Z. \& Salmaki, Y. 2015. Trichome morphology and its significance in the systematic of Phlomoides (Lamiaceae; Lamioideae; Phlomideae). Flora, 213: 40-48.

46. Tüylü, M., Büyükkartal, H.N., Akgül, G. \& Kalyoncu, H. 2017. Marrubium lutescens Boiss. ve M. cephalanthum Boiss. \& Noe subsp. akdaghicum (Lamiaceae)'un gövde ve yaprak özelliklerinin anatomik olarak karşılaştırılması. Süleyman Demirel Üniversitesi Fen Bilimleri Enstitüsü Dergisi, 21(1): 113-117.

47. Upson, T.M. \& Andrews, S. 2004. The Genus Lavandula. A Botanical Magazine Monograph. Royal Botanical Gardens, Kew, London, 442 pp.

48. Uysal, İ. 2003. Stachys thirkei Koch (Kekikgiller) türünün morfolojisi, anatomisi ve ekolojisi üzerinde araştırmalar. Ot Sistematik Botanik Dergisi, 10: 129-141.

49. Xiang, C.L., Dong, Z.H., Peng, H. \& Liu, Z.W. 2010. Trichome micromorphology of the East Asiatic genus Chelonopsis (Lamiaceae) and its systematic implications. Flora, 205: 434-441.

50. Watson, L. \& Dallwitz, M.T. 1978. The families of flowering plants. Oxford University Press, London.

51. Yousefi, K., Soraya, H., Fathiazad, F., Khorrami, A., Hamedeyazdan, S., Maleki-Dizaji, N. \& Garjani, A. 2013. Cardioprotective effect of methanolic extract of Marrubium vulgare L. on isoproterenol-induced acute myocardial infarction in rats. Indian Journal of Experimental Biology, 51(8): 653-660.

52. Yousefi, K., Fathiazad, F., Soraya, H., Rameshrad, M., Maleki-Dizaji, N. \& Garjani, A. 2014. Marrubium vulgare L. methanolic extract inhibits inflammatory response and prevents cardiomyocyte fibrosis in isoproterenol-induced acute myocardial infarction in rats. Bioimpacts, 4(1): 21-27. 
